\title{
ПРИВЛЕЧЕНИЕ И УДЕРЖАНИЕ ВЫСОКОКВАЛИФИЦИРОВАННЫХ СПЕЦИАЛИСТОВ В РЕСПУБЛИКУ ТАТАРСТАН
}

\author{
(c) 2020 Колесникова Юлия Сергеевна \\ доктор экономических наук, \\ главный научный сотрудник отдела воспроизводства трудовых ресурсов и занятости населения \\ Институт демографических исследований ФНИСЦ РАН \\ E-mail:hulia_k@mail.ru \\ (C) 2020 Фахрутдинова Елена Валерьевна \\ доктор экономических наук, профессор, \\ заведующий кафедрой управления человеческими ресурсами \\ Казанский (Приволжский) федеральный университет, Россия, Казань \\ E-mail: efahr@mail.ru \\ (c) 2020 Юрков Дмитрий Васильевич \\ доктор экономических наук, доцент кафедры управления человеческими ресурсами \\ Казанский (Приволжский) федеральный университет, Россия, Казань
}

В работе рассмотрены механизмы привлечения и удержания персонала, занятого научными исследованиями и разработками, врачей. В статье проанализированы показатели обеспеченности врачами, нагрузка на работников сферы здравоохранения в Приволжском федеральном округе. Исследована динамика количества персонала, занятого научными исследованиями и разработками. Выявлен кадровый дефицит в Республике Татарстан в системе здравоохранения и старение кадров, занятых научными исследованиями и разработками. В работе анализируются региональные программы, направленные на нивелирование дефицита кадров в обозначенных сферах в Республике Татарстан и их реализация. Выделены также востребованные профессии такие как инженеры, технологи, механики и др. в отношении которых отсутствуют специализированные региональные программы по привлечению и удержанию. Наличие региональных программ по привлечению и удержанию кадров частично нивелирует проблему нехватки высококвалифицированных специалистов, но тем не менее данные группы специальностей остаются дефицитными в Республике Татарстан. Проведенный анализ данных показал, что наличие региональных программ позволяет стимулировать миграционные процессы и сглаживать дисбаланс на рынке труда, однако желаемые показатели привлечения высококвалифицированных специалистов в Республику Татарстан пока не достигнуты.

Ключевые слова: высококвалифицированные специалисты, механизмы привлечения и удержания кадров, человеческие ресурсы, врачи, персонал, занятый НИР

\section{Основные положения:}

1. В Республике Татарстан в 2020 году выделены 116 профессий высшего образования, которые признаны высоковостребованными.

2. Обеспеченность врачами в Республике Татарстан по итогам 2019 года составила 35,4 на 10 тыс. населения, что ниже нормативного показателя, в 2018 г. Республика заняла по данному показателю 61 место среди регионов РФ.

3. В Республике Татарстан реализуется программа по привлечению врачей-специалистов и врачей клинико-лабораторной диагностики, федеральная программа единовременных выплат, программа надбавок молодым специалистам в бюджетных учреждениях, программа социальной ипотеки и арендного жилья.

4. Количество персонала, занятого научными исследованиями и разработками с 1990-х гг. в РФ снижалось. В то время как в зарубежных странах происходил рост данного показателя, например, в Китае на 9,8\% в период 2000-2016 гг.

\section{Введение}

В период 1990-2000 гг. в РФ происходил значительный спад рождаемости при росте смертности населения, ввиду чего в трудоспособный возраст входят меньшее количество населения. 
Рост рождаемости в РФ начинается только с 2000 г. Восполнение дефицита кадров в ряде отраслей регионов РФ в настоящее время возможно в основном за счет усиления миграционных потоков.

Высококвалифицированные кадры в рамках данной работы следует интерпретировать как население с высшим образованием, обладающее необходимой квалификацией для выполнения работы по специальности.

В Республике Татарстан был сформирован перечень профессий и специальностей, которые будут востребованы и соответствуют приоритетным направлениям развития экономики на 2021-2027 годы. В текущем году в него вошли 767 профессий и специальностей, в том числе 230 специальностей высшего образования, т.е. высококвалифицированные кадры [1].

Среди высококвалифицированных специалистов это медицинский персонал, инженеры, технологи, механики, менеджеры и другие. Кадровый дефицит наблюдается на крупных промышленных предприятиях различных отраслей экономики. Потенциал в развитие потребности высококвалифицированных кадров формируется благодаря развитию нефтехимической и нефтегазовый промышленности, а также особых экономических зон.

\section{Методы исследования}

В работе применены анализ и синтез, индукция и дедукция, сравнение и аналогия. Применен ресурсный подход к анализу человече- ских ресурсов. Исследование носит системный характер. Экономико-статистические методы позволили ранжировать регионы по обеспеченности высококвалифицированными кадрами. Информационную базу исследования составили отчеты министерств Республики Татарстан, статистистические показатели, отчеты Высшей школы экономики, печатная периодика и др.

\section{Результаты}

На начало 2020 года в Республике Татарстан насчитывается 47,5 тыс. медицинских работников. Обеспеченность врачами по итогам 2019 года составила 35,4 на 10 тыс. населения [2]. Нормативным показателем обеспеченности врачами составляет 41 на 10000 населения. В 2018 г. по обеспеченности врачами на 10000 населения Татарстан занимал 61 место среди всех регионов РФ, первое место у г. Санкт-Петербург $-81,2$ врачей на 10000 населения, на втором месте Чукотский автономный округ, на третьем - Республика Северная Осетия - Алания. Средняя нагрузка на 1 врача в Республике Татарстан $-236,8$ человек (рис. 1). Врачи остаются высоко востребованными в регионах России, что не побуждает их к миграции [3].

Присутствует дисбаланс распределения врачей по группам специальностей. Самый высокий дефицит сохраняется по таким специальностям как анестизиолог-реаниматолог, врач скорой помощи, фтизиатры, патологоанатом, кардиолог, неонатолог, офтальмолог, ЛОР-врач. В 35 специальностях из 58 ощущается кадровый

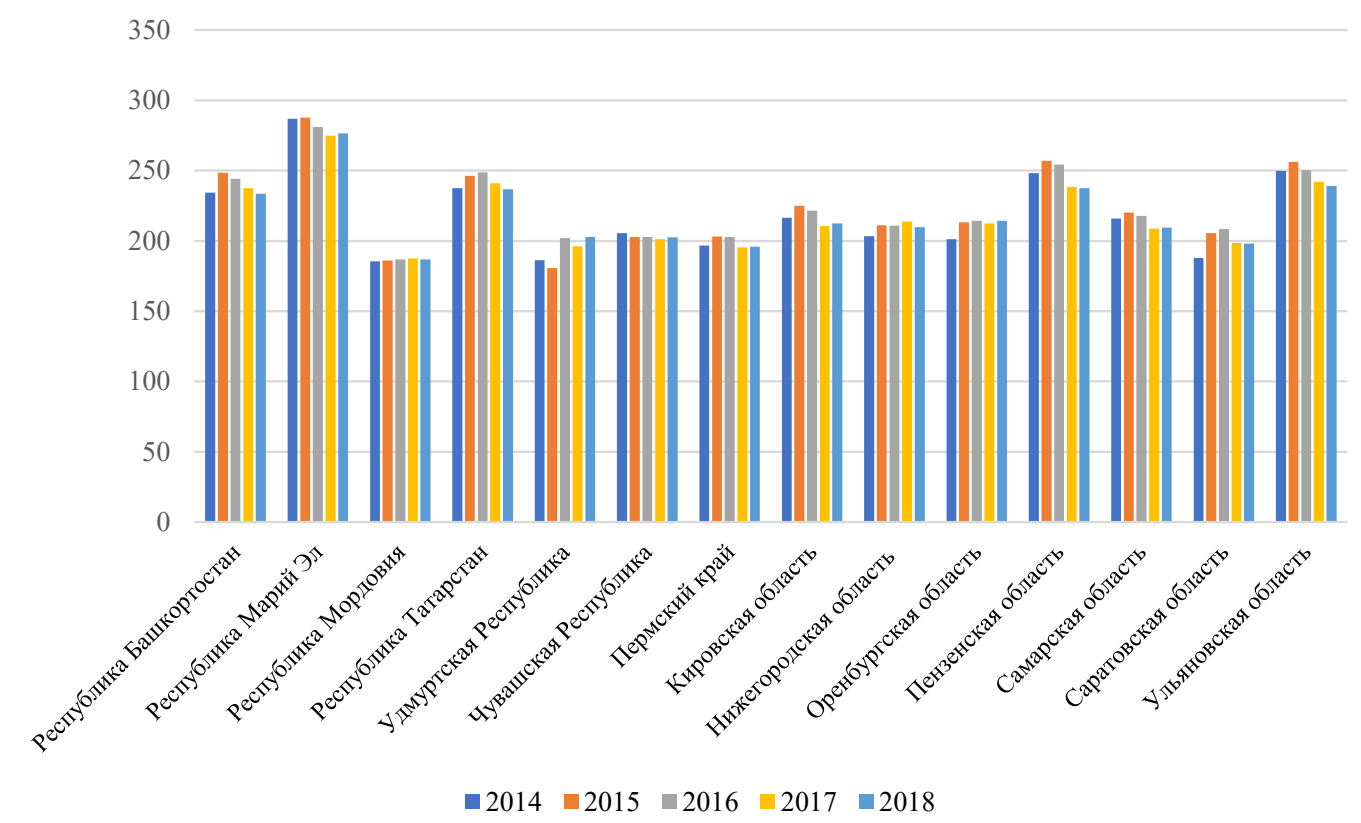

Рис.1. Нагрузка на работников сферы здравоохранения в ПФО [4] 
дефицит [5].

На сегодняшний день потребность во врачах в республике остается на уровне 1,5 тыс. человек. Национальный проект «Здравоохранение» рассчитан до 2024 года, согласно которому для ликвидации дефицита, необходимо привлекать в Республику Татарстан каждый год 300 работников. В 2019 году была положительная динамика, из частных организаций в государственную систему пришло 153 работника, ушло - 109 человек [6]. В настоящее время врачей в пенсионном возрасте в Республике Татарстан работает около $14 \%$, т.е. необходимо также планировать выбытие кадров, которое негативно скажется на показателях обеспеченности врачами и на качестве медицинской помощи как следствие. В 2018 г. в Республике Татарстан наблюдался рост смертности в сравнении с 2017 г. на 1,8\%.

В Республике Татарстан реализуется программа по привлечению врачей-специалистов и врачей клинико-лабораторной диагностики. В рамках данной программы врачам, принятым на работу в государственные учреждения здравоохранения Республики Татарстан на конкурсной основе предоставляется грант в объеме 500 тыс.руб. на социальную ипотеку для переезда в район, где происходит трудоустройство. В 2020 г. планируется увеличить размер гранта до 800 тыс.руб.

В регионе также действуют такие меры соцподдержки, как программа арендного жилья, льготное ипотечное кредитование, возмещение процентной ставки по кредитам, предоставление земельных участков под индивидуальное жилищное домостроение.

Вторым направлением привлечения высококвалифицированных кадров являются специалисты и учёные, ведущие актуальные научные исследования и технологические разработки, для развития экономики Республики Татарстан. Республиканская программа реализуется в рамках программы по оказанию содействия добровольному переселению в Российскую Федерацию соотечественников, проживающих за рубежом на 2020-2022 годы. Планируется привлечь в РФ 197,5 тыс.чел. Реализация программы позволит привлечь на территорию Республики до 2021 года 450 соотечественников [7].

Согласно отчетам Министерства труда, занятости и социальной защиты Республики Татарстан в 2018 г. по данной программе потрачено 647,74 тыс. руб., т.е. исполнение на 13\%, в 2019 г. расходы составили 1510,00 тыс. руб.- исполнение программы на 81,7\%. Плановые показатели финансирования, представлены в таблице 1.

Программа предполагает информирование соотечественников о реализации программы, содействие в первичном жилищном обустройстве (компенсация части арендной платы в течении 6 мес.), обучение по основным программам профессионального обучения, медицинское освидетельствование и оказание медицинской помощи.

Согласно данным Высшей школы экономики за 2019 г. количество персонала, занятого научными исследованиями и разработками с 1990-х гг. в РФ снижалось на 7,5\% в год в период $1990-$ 2000 гг., на 1,8\% в год в период 2000-2008гг и на 0,3\% в год в период 2008-2016 гг. [9] В то время как в зарубежных странах происходил рост данного показателя, например в Китае на 9,8\% в период 2000-2016 гг. (рис. 2).

Кроме того, наблюдалось старение кадров в данной сфере. Если средний возраст занятых в экономике составляет 41 год, то, например, для докторов наук - 63 года, для исследователей 47 лет [11].

\section{Обсуждения}

Таким образом, динамика показателей среднего возраста и показатели занятости в НИР свидетельствуют о необходимости стимулирования привлечения кадров в данную сферу. В Республике действует с 2006 г. программа «Алгарыш», направленная на формирование оседлости кадров в Республике Татарстан, она предполагает обязательства отработки 3 лет на территории Республики всех грантополучателей. Данная программа направлена на следующие категории

Таблица 1. Объем финансирования государственной программы (тыс.рублей) [8]

\begin{tabular}{|c|c|}
\hline Год & Бюджет государственной программы \\
\hline 2019 & 1510 \\
\hline 2020 & 2400 \\
\hline 2021 & 2400 \\
\hline 2022 & 2400 \\
\hline Итого & 8710 \\
\hline
\end{tabular}




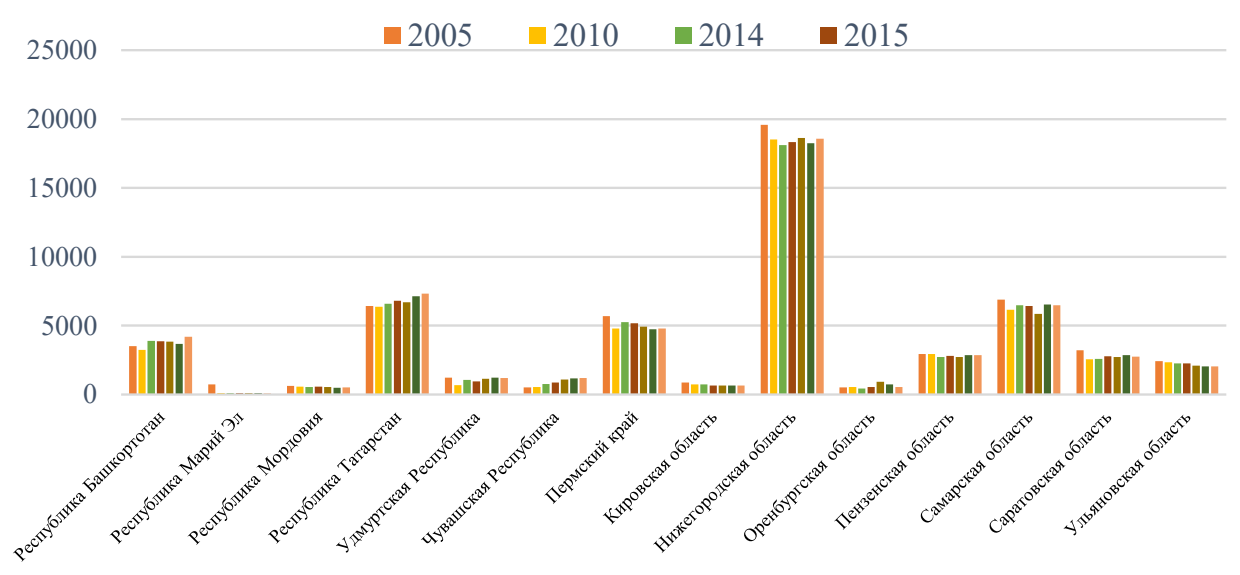

Puc. 2. Персонал, занятый НИР в ПФО (тыс. чел.) [10]

грантополучателей из Татарстана:

- молодые ученые до 35 лет;

- преподаватели и научные сотрудники высшего образования Республики Татарстан;

- работники общеобразовательных учреждений;

- участники программ двойных дипломов;

- образовательные организации высшего образования

- проектные группы

- Worldskills.

Привлечение персонала, занятого НИР является для Республики Татарстан актуальной задачей, Татарстан значительно уступает Нижегородской области по данному показателю в ПФО; Свердловской, Новосибирской, Челябинской, Московской областям, г. Москве и г СанктПетербургу.

\section{Заключение}

Таким образом, по оценкам экспертов профессии высшего образования, в зависимости от показателей развития отраслей хозяйствования, рождаемости, миграции и характера распре- деления высших учебных заведений в ряде регионов появляются дефицитные профессии. В Республике Татарстан дефицит кадров наблюдается среди врачей. На сглаживание дисбаланса спроса и предложения на рынке труда в Республике Татарстан реализуются помимо федеральных программ, ряд региональных программ, направленных на привлечение и удержание медицинских работников. Численность персонала, занятого научными исследованиями и разработкам влияет на изобретательскую активность региона и на его социально-экономическое развитие в условиях информационной экономики. Принятые государственные программы, направлены на привлечение соотечественников, занятых в НИР в РФ. Проведенный анализ данных показал, что наличие региональных программ позволяет стимулировать миграционные процессы и сглаживать дисбаланс на рынке труда, однако желаемые показатели привлечения высококвалифицированных специалистов в Республику Татарстан пока не достигнуты.

\section{Библиографический список}

1. Перечень востребованных профессий и специальностей, соответствующих приоритетным направлениям развития экономики Республики Татарстан на 2021-2027годы. Министерство труда, занятости и социальной защиты Республики Татарстан URL: http://mtsz.tatarstan.ru/perechen-vostrebovannih-professiy-i.htm/ (дата обращения: 27.04.2020)

2. Федеральная служба государственной статистики. Регионы России.URL: https://gks.ru/bgd/regl/b19_14p/ Main.htm (дата обращения: 27.04.2019)

3. Fakhrutdinova E.V., Kolesnikova J.S., Suleimanov T.D., KhalikovA.L. The interrelation of the problems of the youth labour market and the «brain drain»//Life Science Journal. 2014. T. 11. № 6s. C. 473-477.

4. Федеральная служба государственной статистики. Регионы России.URL: https://gks.ru/bgd/regl/b19_14p/ Main.htm (дата обращения: 27.04.2019) 
5. адры решают: чем Татарстан привлекает молодых врачей и почему из частных клиник идут в бюджетные. URL: https://sntat.ru/news/health/05-02-2020/kadry-reshayut-chem-tatarstan-privlekaet-molodyh-vrachey-ipochemu-iz-chastnyh-klinik-idut-v-byudzhetnye-5720829 (дата обращения: 27.04.2019)

6. Кадры решают: чем Татарстан привлекает молодых врачей и почему из частных клиник идут в бюджетные. URL: https://sntat.ru/news/health/05-02-2020/kadry-reshayut-chem-tatarstan-privlekaet-molodyh-vrachey-ipochemu-iz-chastnyh-klinik-idut-v-byudzhetnye-5720829 (дата обращения: 27.04.2019)

7. Согласована программа Республики Татарстан по оказанию содействия добровольному переселению соотечественников, проживающих за рубежом. URL: http://government.ru/docs/36050/ (дата обращения: 27.04.2020)

8. Министерство труда, занятости и социальной защиты PT.URL: http://mtsz.tatarstan.ru/rus/informatsiyastatistika.htm (дата обращения: 27.04.2020)

9. Индикаторы науки. Высшая школа экономики. URL: https:/www.hse.ru/primarydata/in2019 (дата обращения: 27.04.2020)

10. Индикаторы науки. Высшая школа экономики. URL: https:/www.hse.ru/primarydata/in2019 (дата обращения: 27.04.2020)

11. Индикаторы науки. Высшая школа экономики. URL: https:/www.hse.ru/primarydata/in2019 (дата обращения: 27.04.2020) 